\title{
THE REFORM OF CORPORATE GOVERNANCE IN THE UNITED STATES AND THE NEW CHALLENGE OF THE EUROPEAN UNION: THE ITALIAN CASE
}

\author{
Valentina Barbanti*
}

\section{INTRODUCTION}

The scandals of the recent past involving Enron Corp. and other major companies have raised serious concerns about the effectiveness of the governance rules applicable to public companies in the United States. Not surprisingly, corporate governance is one of the main items of the reform outlined by the Sarbanes-Oxley Act of 2002 (Act), ${ }^{1}$ which is the most significant securities legislation affecting public companies to be enacted in the United States since the adoption of the Securities Act of 1933 and the Securities Exchange Act of 1934.

The Act also manifests the new focus of the Securities and Exchange Commission (SEC) on foreign private issuers. ${ }^{2}$ Under the Act, foreign private issuers must now comply with U.S. corporate governance rules; previously, regulation in this area was left to the discretion of home country regulators. The corporate governance listing standards proposed and adopted by the New York Stock Exchange (NYSE) and the Nasdaq Stock Exchange (Nasdaq) which were approved by the SEC on November 4, 2003 (the New Corporate Governance Standards), will also have a significant impact on non-U.S. companies that are listed on the NYSE or trade through Nasdaq. ${ }^{3}$

* Associate Allen \& Overy, Rome and New York; LL.M. (2002), New York University; Master Degree (1997), University of Rome "La Sapienza"; Law Degree (1994). I would like to thank Kenneth Rivlin, Jamaica Potts Szeliga, and Bruno Gencarelli for their encouragement and helpful comments.

1. See 15 U.S.C. $\$ \S 7201-7266$ (2002).

2. See infra note 8 , for the definition of "foreign private issuer."

3. See U.S. Securities and Exchange Commission Release No. 34-48745, available at http://www.sec.gov/rules/sro/34-48745.htm (last visited Dec. 2, 2003) [hereinafter Release No. 34-48745]. On August 16, 2002, the NYSE filed with the SEC amendments to its Listed Company Manual to implement significant changes to its listing standards aimed at helping to restore investor confidence by empowering and ensuring the independence of directors and strengthening corporate governance practices. Id. On March 12, 2003, the NYSE filed with the SEC a revised proposal on director independence for U.S. companies. Id. On April 4, 2003, the NYSE's Board of Directors approved amendments to the NYSE Corporate Governance Listing Standards, and the SEC published those standards for public comment. In response to the comments received, as well as to comments made by the SEC, the NYSE further revised the proposals in an amendment filed with the SEC on October 8, 2003 and October 17, 2003. The NYSE Final Corporate Governance Rules, which were approved by the SEC on November 4, 2003, will be codified in Section 303A of the NYSE Listed Company Manual. 
This new focus in the United States on corporate governance has fed concerns about similar issues in the European Union (E.U.), including, in particular, the extraterritorial application of U.S. law and potential inconsistencies between U.S. and non-U.S. requirements affecting foreign private issuers. Those concerns have led many E.U. Member States-including Italy - to reexamine their existing oversight and governance systems and to consider regulatory reforms patterned after the U.S. model.

The purpose of this Article is to summarize the likely impact that the reform of corporate governance rules in the United States will have on nonU.S. companies, in particular with respect to Italian companies. ${ }^{4}$

Section I highlights the key features of the U.S. reform concerning corporate governance and accountability, including the relevant provisions of the Act (as implemented by the SEC) and the New Corporate Governance Standards. This Section also addresses the recommendations that were issued on January 9, 2003 by the Commission on Public Trust and Private Enterprise (the Conference Board Commission), a U.S. commission investigating issues of corporate governance. ${ }^{5}$ The analysis in Section I focuses on the impact that the new corporate governance rules in the United States may have on E.U. reporting companies. To this purpose, Section I includes a brief overview of the corporate governance system in the E.U. Member States, as it is at present and as it may likely change as a result of the reform of corporate governance in the E.U., which the European Commission is currently considering.

Section II focuses on the Italian legal system of corporate governance, as compared to the U.S. model. The analysis in Section II takes into account

See Corporate Governance Listing Standards (Section 303A Final Rules), at http://www.nyse .com/pdfs/finalcorpgovrules.pdf (last visited Dec. 2, 2003) [hereinafter NYSE Corporate Governance Listing Standards]. In early October 2002, the Nasdaq submitted its own set of corporate governance rules proposals and later updated those changes. See Nasdaq, Summary of Nasdaq Corporate Governance Proposals, at http://www.nasdaq.com/about/Web_Corp_ Gov_Summary\%20Feb-revised.pdf (last updated Feb. 26, 2003). Based on the comments received during the rule-making process, Nasdaq has made a number of changes to the abovementioned proposals, which were approved by the SEC on November 4, 2003. The text of the approval order, as well as Nasdaq's various rule filings, can be found on the Nasdaq's Recent Rule Changes page, at http://www.nasdaq.com/about/RecentRuleChanges.stm (last visited Dec. 2, 2003) [hereinafter Nasdaq's Recent Rule Changes].

4. A thorough outline of the provisions of the Act (and of any relevant rule and recommendation) is beyond the scope of this Comment.

5. See The Conference Board Commission on Public Trust and Private Enterprise, available at http://www.fei.org/download/TCB_PublicTrust2-3.pdf (last visited Dec. 3, 2003). The Conference Board Commission was set up by the Conference Board, a business lobby group formed to address the circumstances that led to the recent corporate scandals in the United States. Id. The president of the Conference Board also announced that the Board has formed a Director's Institute to educate corporate directors throughout the United States. Id. 
the current legal and regulatory framework and the recent suggestions to reform the Italian system to better ensure compliance with the Act. ${ }^{6}$

\section{THE REFORM OF CORPORATE GOVERNANCE IN THE UNITED STATES AND THE E.U. MEMBER STATES}

\section{A. The Extraterritorial Application of the U.S. Reform}

The Act applies to any company or other legal entity that has securities listed on a U.S. exchange or is registered with the SEC, is otherwise required to "file" reports with the SEC, or has filed a registration statement with the SEC and not withdrawn it. ${ }^{7}$ In particular, issuers organized outside the United

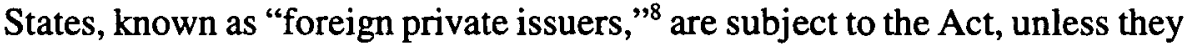
"furnish" rather than "file" material with the SEC pursuant to the so-called Rule 12g3-2(b) exemption from the registration and ongoing reporting requirements of the U.S. securities laws. ${ }^{9}$

Some provisions of the Act have required implementing regulations by the SEC to become enforceable. Although the SEC historically has afforded a great deal of deference to the corporate governance standards of home country jurisdictions, the implementing rules that have been issued to date have provided only a few exceptions for non-U.S. reporting companies. In one of its final rules, the SEC has made it clear that the denial of general exemptions for foreign private issuers complies with the plain language of these rules, which apply broadly to all "issuers." According to the SEC,

6. The analysis in Section II also takes into account the expected reform of corporate rules in the Italian jurisdiction. See Legislative Decree No. 6 of January 17, 2003, G.U. No. 17, Suppl. Ord. (Jan. 22, 2003), which will enter into force in 2004 and will materially change the Italian company law.

7. See 15 U.S.C. $\$ 7201(7)$ (2002), for definition of "Issuer."

8. 17 C.F.R. § $240.3 \mathrm{~b}-4$ (2002). "Foreign private issuer" is defined as any issuer organized outside the United States other than the issuer with (1) more than $50 \%$ of its outstanding voting securities owned of record directly or indirectly by U.S. residents and (2) any of the following: (A) majority of its executive officers or directors being U.S. residents or citizens and (B) more than $50 \%$ of its assets located in the United States or (C) its business administered principally in the United States.

9. 17 C.F.R. \& 240.12g3-2(b). As a general rule, a foreign private issuer is required under Section 12(g) of the Exchange Act to register any class of its securities if the issuer has $\$ 10$ million or more in assets on the last day of its most recent fiscal year and the security is held of record by 500 or more persons worldwide, including 300 or more persons resident in the U.S. Id. Rule 12g3-2(b) provides an exemption from this registration requirement if the foreign private issuer has not obtained a U.S. exchange listing or Nasdaq quotation and applies for the exemption within 120 days of the end of the year in which the thresholds are exceeded. Id. To this purpose, a foreign private issuer must furnish to the SEC, in its initial submission and on a continuing basis thereafter, any material information that it: (i) makes public in its home jurisdiction pursuant to the law of that country; (ii) files with any stock exchange on which its securities are listed; or (iii) distributes to its securities holder. Id. 
imposing the Act's requirements for foreign private issuers also fulfills "the overarching purpose of the Act, which is to restore investor confidence in U.S. financial markets, regardless of the origin of the market participants." 10 This comment, which should explain the position of the SEC with respect to the inclusion of foreign private issuers within the scope of Sections 406 and 407 of the Act, more generally demonstrates the new attitude of the U.S. regulator to broadly apply a number of the corporate governance requirements provided for by the Act.

The new approach could result in U.S. oversight of European companies, which already are subject to their own nation's regulators. Furthermore, some provisions that do not appear to apply to non-U.S. companies may affect local market practice and U.S. courts may be less sympathetic to non-U.S. companies that do not meet the same standards as U.S. companies. ${ }^{11}$

In addition to actions by the U.S. federal government, the New Corporate Governance Standards will have both immediate and long-ranging effects on the organization and operation of non-U.S. listed companies. The NYSE has clarified that, as applied to foreign private issuers, its corporate governance listing requirements continue generally to defer to home-country practices. With respect to Section 303A (11) of the NYSE Corporate Governance Rules, the NYSE noted that, "both SEC rules and NYSE policies have long recognized that foreign private issuers differ from domestic companies in the regulatory and disclosure regimes and customs they follow, and that it is appropriate to accommodate those differences." 12 Nonetheless, foreign private issuers that are listed on the NYSE would be required to disclose any significant ways in which their corporate governance practices differ from those followed by domestic companies. ${ }^{13}$ Similarly, foreign private issuers will need to disclose any exemptions to Nasdaq's corporate governance requirements, as well as any alternative measures taken in lieu of the waived requirements. ${ }^{14}$

10. See Final Rules Release, U.S. Securities and Exchange Commission, Final rule: Disclosure required by Sections 406 and 407 of the Sarbanes-Oxley Act of 2002, 17 C.F.R. 228, 229 and 249, Release Nos. 33-8177; $34-47235$ (Jan. 24, 2003), available at http//www.sec.gov/rules/final/33-8177.htm (last visited Oct. 4, 2003).

11. In particular, it is possible that courts in the United States will be presented with actions challenging the applicability of the Act to foreign issuers. Whether the Act will withstand any such judicial scrutiny in relation to foreign issuers is uncertain.

12. See NYSE, Corporate Govemance Rule Proposals Reflecting Recommendations from NYSE Corporate Accountability and Listing Standards Committee, at 16, available at http://www.nyse.com/pdfs/corp_gov_pro_b.pdf (last visited Dec. 2, 2003).

13. See NYSE Corporate Governance Listing Standards, supra note 3, at 16. Foreign private issuers are allowed to follow home country practice in lieu of the provisions of the new rules, except that such issuers are required to comply with the requirements relating to audit committees and notification of non-compliance mandated by Rule 10A-3. Id. at 2 .

14. See Release No. 34-48745, supra note 3; Nasdaq's Recent Rule Changes, supra note 


\section{B. The U.S. model and the European Union}

The concerns raised by the extraterritorial application of the Act, namely the risks of duplication and excessive red tape for E.U. companies, have prompted the European Commission to carefully reconsider the existing corporate governance framework in the E.U.

In September 2001, the European Commission established a Group of High Level Company Law Experts with the purpose of initiating a discussion on the need for a modernization of company law in E.U. Member States. ${ }^{15}$ In the wake of the Enron scandal, the European Commission extended the mandate of these experts to review a number of issues related to best practices in corporate governance, such as the role of non-executive and supervisory directors, the remuneration of management, and the responsibility of management for financial statements. ${ }^{16}$ On November 4, 2002, the experts presented a wide array of recommendations in the "Final Report of the Group on a Modern Regulatory Framework for Company Law in Europe."17 These recommendations take into account the provisions of the Act concerning corporate governance, while accommodating the particular situations of individual E.U. Member States.

On May 21, 2003, in light of the suggestions made by the experts, the European Commission presented its action plan on "Modernizing Company Law and Enhancing Corporate Governance in the European Union." 18 This action plan outlines the approach that the European Commission intends to follow, specifically in the area of company law and corporate governance in the short term (2003-2005), medium term (2006-2008), and long-term (2009 onwards).

15. See The European Commission, Financial Reporting and Company Law, A Modern Regulatory Framework for Company Law in Europe: A Consultative Document of the High Level Group of Company Law Experts, at http://europa.eu.int/comm/internal_market/en/ company/company/modern/consult/1_en.htm (last visited Oct. 31, 2003).

16. See id. In particular, the discussion was focused on the concerns regarding better information for shareholders and creditors (including a better disclosure of corporate governance structures and practices), the strengthening of the duties of the board and of shareholders' rights, and minority protection. Id.

17. See The European Commission, Financial Reporting and Company Law, A Modern Regulatory Framework for Company Law in Europe: Final Report of the High Level Group of Company Law Experts, at http://europa.eu.int/comm/internal_market/en/company/company/ modern/index.htm (last updated Nov. 4, 2002) [hereinafter Financial Reporting and Company Law, Final Report].

18. See Communication from the Commission to the Council and the European Parliament-Modernising Company Law and Enhancing Corporate Governance in the European Union-A Plan to move forward, at http://europa.eu.int/eur-lex/pri/en/dpi/cnc/doc/2003/ com2003_0284en01.doc (last visited Dec. 3, 2003) [hereinafter Action Plan]. On September 22,2003 , the Council of the European Union welcomed the presentation of such Action Plan, which has been open to public consultation for three months. Simultaneously with the Action Plan, the European Commission has published ten priorities for improving and harmonising the quality of statutory audit throughout the E.U. Id. 
The European Commission's recommendation is that the E.U. Member States should adopt a common approach covering a few essential rules and should ensure adequate coordination of national corporate governance codes. ${ }^{19}$

As a matter of fact, in most of the E.U. Member States the main corporate governance rules are provided for by corporate governance codes. ${ }^{20}$ Approximately forty codes have been issued to date, with every Member State except Austria and Luxembourg having at least one code. ${ }^{21}$ All of these codes call for voluntary adoption of their substantive provisions. Under some codes, a coercive pressure is exerted through "comply or explain" disclosure requirements, ${ }^{22}$ as the tendency for some companies may be to "comply" rather than to explain. Even where a "comply or explain" disclosure mandate exists, a company is generally free to choose not to follow the code's prescriptions. Though the corporate governance codes are voluntary in nature, they have a significant influence on corporate governance practices. By and large, the code recommendations are remarkable in their similarity and serve as a converging force. The major differences in corporate governance practices among E.U. Member States result from differences in company law and securities regulation rather than from differences in code recommendations.

As a general rule, in E.U. Member States, corporations are subject to the control of a shareholder body (typically organized through a general meeting), a supervisory body, and a management body. The differences in corporate governance practices across Member States relate to the structure of the supervisory body, though similarities in actual board practices are significant.

In particular, either the unitary or the two-tier board structure can be used. ${ }^{23}$ Although there is an extensive and ongoing academic discussion on the advantages and disadvantages of these systems, there is no consensus as to which one of the two is a more effective monitoring body. In unitary board

19. In particular, largely in line with the suggestions contained in the Financial Reporting and Company Law, Final Report, the European Commission's (legislative and non-legislative) proposals contained in the Action Plan are aimed at achieving the following goals: (i) enhancing corporate governance disclosure; (ii) strengthening shareholders' rights; (iii) modernising the board of directors; and (iv) coordinating corporate governance efforts of Member States. See id.

20. A "corporate governance code" generally refers to a non-binding set of principles, standards, or best practices issued by a collective body and relating to the internal governance of the corporation. See e.g., Russia's Corporate Governance Code, available at http://12.107. 100.170/Corp\%20Governance/Corp.\%20Governance-\%20summary.htm (last visited Nov. 7, 2003); Austria's Corporate Governance Code, available at http://www.andritz.com/cg-engl.pdf (last visited Nov. 7, 2003).

21. The vast majority of these codes (twenty-five) were issued after 1997. The United Kingdom accounts for the largest number of codes (almost one-third of the total).

22. Disclosure against a code is referred to as disclosure on a "comply or explain" basis whenever the code advocates disclosure by listed companies of the degree to which they comply with the code recommendations.

23. In Austria, Germany, Denmark, and the Netherlands the two-tier structure is predominant. Italy, Belgium, Finland, France, Greece, Ireland, Luxembourg, Portugal, Spain, Sweden, and the United Kingdom have adopted the unitary board structure. 
systems, the board of directors is charged with leading and controlling the business and generally delegating day-to-day operations to one or more managers. ${ }^{24}$ Two-tier board structures recognize a more formal distinction between the supervisory and the managerial bodies. In either system, the supervisory body is generally charged with appointing, dismissing and remunerating senior managers, ensuring the integrity of financial reporting and control system, as well as the general legal compliance of the corporation. However, the need for a supervisory board that is distinct from management to ensure accountability and provide strategic guidance is recognized in most, if not all, of the E.U. Member States. Under the unitary system, the distinction between the unitary board and the senior management team is accomplished through the appointment of outside (or non-executive) directors and some "independent" 25 directors to the supervisory body. Under the two-tier system, the need for independence between the supervisory and the management bodies is generally accomplished by warning against the practice of naming retired managers to the supervisory board.

In light of the above, it will be useful to highlight the key features of the U.S. reform and to consider the relevant implications for foreign private issuers, including E.U. reporting companies.

\section{The Corporate Governance Structure}

The corporate governance structure of U.S. public companies is significantly different from either of the two systems used in the E.U. Member States. Typically, chief executives have an immense power. The roles of the chairman and the chief executive officer (CEO) are often combined and the CEO can exert a substantial influence over the boardroom. Furthermore, directors of two companies often have interlocking relationships ${ }^{26}$ and potential conflict of interest may arise from this "incestuous" position. Recent surveys have also shown that thirteen percent of the companies listed on the NYSE do not have a majority of independent directors and approximately twenty percent of such companies do not even have a board-level nominating committee, independent or otherwise. ${ }^{27}$ Under such circumstances, boards have often either lacked the structure and the information to perform their

24. In several countries, such as Denmark, Finland, and Sweden, the law provides that for companies of a certain size or type a general manager or managing director must be appointed. In such instances, managerial power is not wholly delegated at the option of the unitary supervisory body.

25. "Independence" generally involves an absence of close family ties or business relationships with company management and the controlling shareholder(s).

26. "Interlocking relationship" means that the CEO of company A sits on the board of company $B$ and vice versa.

27. See The Way We Govern Now, ECONOMIST, Jan. 9, 2003, at http://wwwunix.oit.umass.edu/ kazemi/640/govern.pdf (concerning the outcome of a survey in 2002 by the Investor Responsibility Research Centre). 
roles properly, or they have simply abdicated their responsibilities to oversee the CEO's performance. The failure of corporate responsibility in the "Enron cases" has clearly demonstrated the need to ensure sound corporate governance through the active and informed participation of independent directors who can focus on the best interests of the corporation and are empowered effectively to exercise their responsibilities. ${ }^{28}$

In the attempt to bring about actual change and avoid the concerns raised by the concentration of power at the top of corporations, a large number of voices in the United States have suggested importing the European model of a chairman who is separate from the CEO. This solution should establish a proper balance between managing the corporation and providing independent directors with the powers and resources they need to perform their role.

In this regard, the Conference Board Commission has suggested three possible approaches. The first recommendation is that companies consider separating the offices of Chairman and CEO and requiring that the Chairman be one of the independent directors. Alternatively, separate individuals should perform the roles of the Chairman and CEO, and a "Lead Independent Director" should be appointed if the chairman is not "independent" (according to the strict definition of independence set forth by the New Corporate Governance Standards) ${ }^{29}$ Finally, where boards do not choose to separate the Chairman and CEO positions, or when such boards are in transition to a structure where the positions will be separated, a "Presiding Director" position should be established. Each of these alternatives represent a radical break from the tradition that most U.S. corporations follow. Going even further, the Conference Board Commission has recommended that boards that choose not to take any of these approaches should also explain the reasons therefor, and how the board structure that they employ ensures the objective of strong and independent board leadership.

28. This issue was also highlighted by the Task Force on Corporate Responsibility, which was appointed by the President of the American Bar Association to examine systemic issues relating to corporate responsibility arising out of the traumatic collapse of Enron and other Enron-like situations. See Michael R. McAlevey, Practising Law Institute, Preliminary Report of the ABA Task Force on Corporate Responsibility: Understanding the Sarbanes-Oxley Act of 2002, at 169 (2002).

29. According to the NYSE and Nasdaq, for a director to be deemed independent, the board must affirmatively determine that the director has no material relationship with the listed company (either directly or as a partner, shareholder, or officer of an organization that has a relationship with the company); furthermore, certain relationships automatically preclude a board finding of independence (e.g., according to the NYSE Corporate Governance Listing Standards, inter alia, a director who is an employee, or whose immediate family member is an executive officer, of the company may not be considered independent until three years after his employment ends). See Release No. 34-48745, supra note 3, at 36; NYSE Corporate Governance Listing Standards, supra note 3, at 4-6. 


\section{Financial Certifications and the New Requirements for Executives}

\section{Directors}

To raise the bar for corporate accountability, the Act places new significant demands on the $\mathrm{CEO}$ and $\mathrm{CFO}$ of issuers with reporting obligations under the Exchange Act of 1934.

According to Section 302(a), the chief executives must certify in each periodic report that they have "reviewed" such report and that, based on their knowledge, there are no materially false statements or material omissions therein; that the report fairly presents the issuer's financial condition and results of operations; that the signing officers are responsible for establishing and maintaining internal disclosure controls and procedures, have evaluated the effectiveness of the internal controls within the last ninety days and have presented in the report their conclusions; and finally, that they have disclosed internal control deficiencies and any fraud by management or employees with a significant role in those internal controls to the auditors and the audit committee of the board of directors. ${ }^{30}$ In the final rules issued on August 29, 2002 , the SEC specified that these requirements are applicable to foreign private issuers, except for non-U.S. reporting companies relying on the Rule 12g3-2(b) exemption from registration for a class of securities under the Exchange Act of 1934. ${ }^{31}$ In response to doubts raised by Section 302, the SEC has made it clear that a foreign private issuer is not required to include a certification with the semi-annual report on Form 6-K, which non-U.S. reporting companies must file if they have a class of securities registered under the Exchange Act. ${ }^{32}$

The Act also requires, under Section 906(a), that the CEO and CFO certify in each periodic report containing the issuer's financial statements that the report fully complies with applicable reporting requirements and that the information contained in the report "fairly presents, in all material respects, the financial condition and results of operations of the issuer." 33 This provision even imposes criminal liability for failure to file the required

30. See 15 U.S.C. $\$ 7241$ (2002). The certification requirement applies to reports filed with respect to periods ending after August 29, 2002.

31. See Final Rules Release, supra, note 10.

32. Foreign private issuers that are required to file periodic reports with the SEC must furnish on Form 6-K material information about the issuer or its subsidiaries that the issuer: (i) makes public voluntarily or pursuant to the law of the jurisdiction of its domicile or incorporation; (ii) files with a stock exchange on which its securities are traded and which was made public by such exchange; or (iii) distributes to its security holders. Reports on Form 6-K must be provided to the SEC and each U.S. stock exchange on which any security of the issuer is listed promptly after the requisite information is made public as described above. Foreign private issuers are not required to include the certification under Section 302 of the Act with the semi-annual report on Form 6-K, as the SEC deems Form 6-K a current rather than a periodic (i.e. annual or quarterly) report. See Certification of Disclosure in Companies' Quarterly and Annual Reports, Exchange Act Release No. 33-8124, 67 F.R. 57276 (Sept. 9, 2002).

33. Sarbanes-Oxley Act of 2002, H.R. 3763, 107th Cong. \$ 906(b) (2002). 
certification. ${ }^{34}$ Although the Section 906 and Section 302 certifications are similar in many respects, CEOs and CEOs of reporting companies will each have to provide two separate certifications.

The certification requirements under the Act need to be harmonized with the requirements to which an E.U. reporting company is subject in its home country. In order to ensure compliance with these requirements, non-U.S. reporting companies should begin establishing appropriate internal procedures to reduce the risk for the officers signing the required certifications. Nonetheless, under the company laws of E.U. Member States, the responsibility for the probity of financial statements of the company is primarily a collective responsibility of the board: in a one-tier structure, this is a collective responsibility of both executive and non-executive directors; in a two-tier structure, this is the collective responsibility of both the managing directors and the supervisory directors. ${ }^{35}$ The collective responsibility is an appropriate mechanism to avoid a limited number of board members, in particular certain executive directors whose performance is to be reflected in financial statements, having a decisive role in determining their content. In the view of the Group of High Level Company Law Experts, the reform of corporate governance in the E.U. Member States should not change the requirement of a collective responsibility of the full board. On the contrary, the recommendation under the Report is that this collective responsibility extend to all statements on the company's financial position and on non-financial data, subject to very limited exceptions. ${ }^{36}$

\section{The Independent Oversight}

One goal of the U.S. reform effort is to change the current corporate reality in the United States, where senior management plays a significant role in the selection, nomination, and remuneration of directors, as well as in selecting their committee assignments, in setting agendas for their meetings, and in evaluating their performance.

The need for reform in this area has been emphasized by the Conference Board Commission, who has suggested "that the independent Chairman, [the] Lead Independent Director, or the Presiding Director should have ultimate approval over the information flow that goes to the board and should chair frequent, regular meetings of the non-management directors." ${ }^{37}$ This

34. In the same direction, under the NYSE Corporate Governance Listing Standards, each CEO would be required to certify in the annual report to shareholders that he or she is not aware of any violation by the listed company of the NYSE corporate governance standards. See NYSE Corporate Governance Listing Standards, supra note 3, at 17.

35. This is reflected in many Member States in the requirement that all executive, nonexecutive, and supervisory directors sign the annual accounts of the company.

36. See Financial Reporting and Company Law, Final Report, supra note 17, at 9.

37. The Conference Board Commission, supra note 5. 
recommendation raises potential problems, however, as steering the flow of information and setting the agenda determine corporate control, and thus, are of the essence.

Similarly, the requirement for directors to meet regularly in "executive sessions," which is provided for by the New Corporate Governance Standards, may raise the alarm of many chief executives. ${ }^{38}$ As a practical matter, large companies do not usually hold such meetings, as they would give directors the chance to assess whether or not chief executives have really fulfilled their role and whether the agenda that they set covers the right points.

Under the New Corporate Governance Standards, corporations should set a new requirement that a majority of the board consist of independent directors, within the meaning of a tightened definition of independence. However, this requirement should not apply to foreign private issuers. ${ }^{39}$ The Conference Board Commission went even beyond and "urge[d] boards [to] be composed of a substantial majority of independent directors." 40

In the system outlined by the Act, the goal of an independent oversight, especially in those areas where there is a specific need for disinterested monitoring by non-executive and supervisory directors, can be accomplished through the establishment of "functional committees." 41 In particular, the Act requires that audit committees comprised solely of independent directors ${ }^{42}$ take a more active role in the governance structure of U.S. corporations. According to Section 301, the audit committee should have significantly greater authority and responsibility than has been customary in the United States. Such committee will be accountable "for the appointment, compensation, and oversight of . . . any registered public accounting firm employed by the issuer"; will be required to "establish procedures for the receipt, retention and treatment of complaints received by the issuer regarding accounting, internal accounting controls, or auditing matters," including those submitted anonymously by employees; and finally, will have the authority to engage, and determine the fees of, independent counsels and other advisors, as necessary. ${ }^{43}$ It was not clear how the Act would be applied where the requirements under Section 301 conflict and could not be harmonized with requirements to which non-U.S. reporting companies are subject in their home country or other primary market. However, the SEC was required to adopt rules implementing

38. See Release No. 34-48745, supra note 3.

39. See id. at 36.

40. The Conference Board Commission, supra note 5 (emphasis added).

41. Sarbanes-Oxley Act $\S 301$.

42. Under Section 301 , the need for the members of the audit committee to be "independent" means that they cannot be an affiliated person of the issuer or any subsidiary thereof and that they cannot accept any "consulting, ad visory, or other compensatory fees" from the issuer, other than in the capacity as a member of the audit committee, the board of directors, or any other board committee. See 15 U.S.C. 78 \& 10 A(m).

43. Sarbanes-Oxley Act $\S 301$. 
the provision of Section 301. In its release of January $8,2003^{44}$ the SEC proposed a limited exemption from the independence requirements to address concerns over conflicts between the proposed requirements and the laws of some foreign private issuers' home jurisdictions. As a result, foreign private issuers with board of auditors or similar bodies or statutory auditors meeting the requirements of the Act should be exempt from the requirements regarding the independence of audit committee members. ${ }^{45}$

In addition to the audit committees, both the recommendations issued by the Conference Board Commission and the New Corporate Governance Standards have urged companies to establish a nominating corporate governance committee ${ }^{46}$ and a remuneration committee ${ }^{47}$ composed entirely of independent directors (or functional equivalent consisting solely of independent directors). ${ }^{48}$

This functional committee approach has been supported by the Group of High Level Company Law Experts also with respect to the reform of corporate governance in the E.U. Member States. The Report does not express any view as to how the full one-tier board or supervisory board in the two-tier structure should be constituted or to what extent independent non-

44. See Standards Relating to Listed Company Auditor Committees, Exchange Act Release No. 33-8173; 34-47137, 17 C.F.R. \$§ 228-229, 240, 274 (Jan. 8, 2003).

45. Id. The SEC proposal provides that non-management employees would be permitted to sit on the audit committee of a foreign private issuer if the employee is elected or named to the board of directors or audit committee of the foreign private issuer pursuant to home country legal or listing requirements. Id. In conjunction with the implementation of Section 301, the SEC has adopted rules implementing Section 407, according to which reporting companies (other than registered investment companies), including foreign private issuers, are required to disclose in their annual reports filed pursuant to the Exchange Act of 1934 whether they have at least one "audit committee financial expert" serving on its audit committee. Id. Unlike domestic issuers, non-U.S. reporting companies currently are not required to disclose whether their audit committee financial members are independent. $I d$. However, the SEC has determined to eventually include foreign private issuers within the scope of Section 406 and require such disclosure (by amending Forms $20-\mathrm{F}$ and 40-F in conjunction with the rules implementing Section 301). See Certification of Management Investment Company Shareholder Reports and Designation of Certified Shareholder Reports as Exchange Act Periodic Reporting Forms; Disclosure Required by Sections 406 and 407 of the Sarbanes-Oxley Act of 2002, Exchange Act Release No. 34-47262, 68 F.R. 5348 (Jan. 27, 2003) [hereinafter Certification of Reports Release].

46. See Standards Relating to Listed Company Auditor Committees, supra note 44 . The nominating or governance committee should be responsible for nominating qualified candidates to stand for election to the board, monitoring all matters involving corporate governance, and making recommendations to the full board for actions in governance matters. See Release No. $34-48745$, supra note 3 , at 38 .

47. See id. at 39.

48. See The Conference Board Commission, supra note 5. In the view of the Conference Board Commission, U.S. corporations that intend to achieve the goal of effective boards should also establish "a three-tier director evaluation mechanism." Id. This mechanism "would include evaluation of the performance of the board as a whole, the performance of each committee and [that] of each individual director, as necessary." Id. 
executive or supervisory directors should be members of it. Nonetheless, the Group has taken the view that for all listed companies in the E.U. it should be ensured that, within the board, and to the extent these are board matters and not for the shareholders to decide, the executive directors nomination and remuneration and the accounting audit for the company's performance should be decided upon exclusively by non-executive or supervisory directors, who are in the majority independent. ${ }^{49}$

Unlike the U.S. regulator, the Group rejected the requirement for nomination and audit committees to consist exclusively of independent nonexecutive or supervisory directors as a European rule. ${ }^{50}$ Reasonably, this is due to the fact that the Group had to take account of particular situations relevant to board structure in the E.U. Member States, such as the existence of controlling shareholders and boards that are partly determined by employees. $^{51}$ It is clear that representatives of controlling shareholders and employees of the company normally could not be considered to be independent, but it would have gone too far to exclude them completely from participating in these key areas. Requiring oversight by non-executive or supervisory directors who are in the majority independent would ensure a sufficient level of independent oversight, while taking into account the specific legal requirements in the E.U. Member States.

49. Financial Reporting and Company Law, Final Report, supra note 17. In the Group's view, "independent" means "independent in the operational business of the company and of those who take primary responsibility as executive directors, and also not receiving any benefit from the company other than their fully disclosed remuneration as non-executive or supervisory directors." Id.

50. Id. As suggested under the Report, the European Commission should rapidly issue a Recommendation to Member States that they have effective rules in their company laws or in their national corporate governance codes concerning principles on independence and including a list of relationships that would lead a non-executive or supervisory director to be considered as not independent. Id.

51. Generally, both the unitary board of directors and the supervisory board (in the twotier structure) are elected by shareholders through participation in general meetings. However, in certain Member States (such as Austria, Denmark, Germany, Luxembourg and Sweden), employees of companies of a certain size have the right to elect some members of the supervisory body. In Finland and France, the company articles of incorporation may provide for such a right. Under the law of some Member States, work councils may also have an advisory voice on certain issues addressed by the supervisory body, as in the Netherlands and France. In particular, in the Netherlands, where the supervisory board is self-selecting, a new legislation is currently pending which would give employees a role in nominating (but not electing) supervisory board members in structure regime companies, whilst the right of election is given to shareholders. The Dutch Corporate Governance Code: Principles of Good Corporate Governance and Best Practices Provisions, Draft, July 1, 2003, available at corpgov.nl/page/downloads/ Conceptcode\%20Engels\%20DEFINITIEF.pdf (last visited Nov. 7,2003 ). 


\section{Executive Compensation}

The Act contains two important provisions concerning executive compensation. First, Section 304(a) provides for the obligation on the part of the CEO and CFO to disgorge certain bonuses, equity-based compensation, and profits from equity transactions in connection with certain restatement of financial statements "due to the material noncompliance of the issuer, as a result of misconduct, with any financial reporting requirement under the securities laws." 52

Second, under Section 402(a), issuers are prohibited from making loans or extending credit to directors and executive officers, subject to very limited exceptions relating mainly to U.S. financial institutions. ${ }^{53}$ Issuers also cannot materially modify or renew any existing loans. ${ }^{54}$ Given the broad scope of this provision, non-U.S. reporting companies should consult with counsel before authorizing or making any payments or advancing any funds to, or for the benefit of, executive officers or directors that might be viewed as a loan or extension of credit, even if the payments are not prohibited in the company's home country or are even required by an employment agreement or other contract.

\section{Ethical Conduct}

Under the reform, the challenge for U.S. listed companies, as well as for foreign private issuers, is to create a corporate culture, which promotes ethical conduct on the part of the organizations and its employees by supporting responsible behaviors and building environments in which employees take the initiative to address misconduct.

To this purpose, the Act provides for whistleblower protection. Under Section 806, employees are protected against retaliatory discharge or other adverse employment action for providing information to supervisors, the U.S. Government, or the U.S. Congress regarding conduct that the employee reasonably believes violates U.S. securities or antifraud laws. ${ }^{55}$ Though it is not clear how this provision will be effective in the case of foreign private

52. 15 U.S.C. $\$ 7241(2002)$.

53. 15 U.S.C. $78 \& 7243$ (2003). The Act contains two exceptions designed to mitigate this burden for banks and other financial institutions; however, only one of these exceptions is likely to be helpful to non-U.S. financial institutions. Id. One exception generally permits consumer loans made in the ordinary course of business, of the same type, and on the same terms made generally available to the public (home mortgages should also be permitted if they meet these requirements). Id. The other exception exempts loans made by banks and thrifts that are insured by the U.S. Federal Deposit Insurance Corporation and will not apply to non-U.S. banks because they are not FDIC-insured. Id.

54. Id.

55. Sarbanes-Oxley Act $\$ 806$. 
issuers, non-U.S. companies will need to review their policies for possible change in light of this requirement.

In addition, Section 406 of the Act directs the SEC to adopt rules requiring public companies to disclose whether or not, and if not, why not, the company has adopted a code of ethics for senior financial officers. ${ }^{56}$ On January 24,2002 , the SEC made it clear that foreign private issuers will have to provide the new code of ethics disclosure in its annual report (filed pursuant to the Exchange Act of 1934), just as a domestic issuer would. However, in contrast to a domestic issuer, a non-U.S. reporting company will not have to provide in a current report "immediate disclosure" of any change to, or waiver from, the company's code of ethics for its senior financial officers and principal executive officer. ${ }^{57}$

Listed companies would be required also by NYSE and Nasdaq to adopt a code of business conduct and ethics for directors, officers, and employees that addresses a variety of subjects, including conflict of interest. ${ }^{58}$ The Conference Board Commission recommended policies and procedures that define and demand ethical conduct and enforce companies' code of conduct and suggested that a committee of the board should oversee ethics issues. These requirements could clearly overlap or conflict with the code of ethics provisions in foreign private issuers' home jurisdictions.

\section{THE U.S. MODEL AND THE ITALIAN SYSTEM OF CORPORATE GOVERNANCE}

\section{A. The Legal Framework and the Corporate Governance Code in Italy}

The issue of corporate governance has been the object of an intense debate in Italy between those who advocate a form of binding regulation and those who would leave any organizational choice to companies' discretion.

Under the current legal framework, the main corporate governance rules are provided for by the Italian Civil Code (the ICC) ${ }^{59}$ and by the consolidated law on financial intermediation amending the ICC, ${ }^{60}$ as implemented by the

56. 15 U.S.C. $\$ 7264$ (2003).

57. Certification of Reports Release, supra note 45. The SEC is adopting the requirement that a foreign private issuer disclose any such change or waiver that has occurred during the past fiscal year in its Exchange Act annual report. Id.

58. See Release No. 34-48745, supra note 3, at 41; NYSE Corporate Governance Listing Standards, supra note 3, at 15,21. The Nasdaq's code of conduct requirement will be effective beginning May 4, 2004. See NASDAQ Bulletin to Issuers on the Nasdaq's Recent Rule Changes, supra note 3.

59. See Regio Decreto No. 262 (Mar. 16, 1942) (as amended).

60. See Legislative Decree No. 58 (Feb. 24, 1998); Gazz.Uff. no. 71 (Mar. 26, 1998). 
regulations issued by the "Commissione Nazionale per le Societa' e la Borsa" (Consob). ${ }^{61}$

Furthermore, the Italian corporate governance code sets forth "best practice" rules for companies that are listed on the Italian regulated markets. The corporate governance code was drafted in 1998, and subsequently revised, ${ }^{62}$ by a committee comprised of distinguished representatives of the Italian economical and financial community, upon the request of the chairman of Borsa Italiana, Mr. Stefano Preda. The underlying assumption was that such a code (the Preda Code), if used as a guide to best practice, could reassure the investor community as to the existence in listed companies of a clear and well-defined organizational model with an appropriate division of responsibilities and powers along with a proper balance between management and control. As is the case of most of the corporate governance codes issued in the E.U. Member States, the Preda Code is consistent with the "freedom with accountability" principle, and thus, it is voluntary and not mandatory. However, companies might be required to disclose the level of compliance with the recommended standards in a "comply or explain" manner. ${ }^{63}$

Upon the implementation of the Legislative Decree No. 6 of January 17, 2003 , the Italian system of corporate governance will materially change. ${ }^{64}$ In particular, upon the reform, a company will be able to choose among three models of corporate governance:

(i) the traditional system, which reflects the current organizational structure based on the board of directors (elected by the shareholders' meeting), which manages the business and affairs of the company and the board of statutory auditors, which monitors the activity of the board of directors; or

(ii) the two-tier system (patterned after the German model), according to which a management board manages the business and affairs of the company, and a supervisory board (appointed by the shareholders' meeting) is responsible, among others, for monitoring, appointing,

61. Consob is the public authority responsible for regulating the Italian securities market. See International Regulatory Information, at http://www.atmarkets.org/content/international regulations.asp (last visited Dec. 2, 2003).

62. See BORSA ITALIANA, CORPORATE GOVERNANCE CODE (translated) at http://www. borsaitalia.it/opsmedia/pdf/8077.pdf (last visited Nov. 7, 2003) [hereinafter Preda Code]. The latest revision is dated July 2002 . Id.

63. In particular, the committee that drafted the Preda Code invited Borsa Italiana S.p.A. to acknowledge the existence of the Preda Code and to provide for listed companies to report, through procedures agreed with the same committee, on the organizational model they have chosen and the extent to which they have adopted the Preda Code.

64. See supra text accompanying note 6. 
and removing the members of the management board; or

(iii) the unitary system (patterned after the UK model), which recognizes a board of directors (appointed by the shareholders' meeting) with general operating powers and a management control committee (established within the board of directors and composed of nonexecutive and independent directors), which monitors the executive directors. ${ }^{65}$

Unless the company expressly elects a specific model under its articles of incorporation, the traditional system shall apply ${ }^{66}$ Furthermore, most of the general provisions that are applicable to the board of directors in the traditional system (e.g. those relating to duties and powers, conflict of interests, etc.) may also apply to the management board in the two-tier system and to the board of directors in the unitary system. ${ }^{67}$ Similarly, most of the general provisions that are applicable to the board of statutory auditors in the traditional system may apply to the supervisory board in the two-tier system and to the management control committee in the unitary system. ${ }^{68}$

Therefore, the analysis in Section II will focus on the corporate governance structure under the traditional system.

\section{B. The U.S. Model and the Italian system}

In particular, this Section will provide a brief overview of the Italian corporate governance structure and will address a direct comparison between the model outlined by the Act and the system under Italian law, with an assessment of the implications of the Act on dual U.S. and Italian listed companies, where relevant.

\section{The Corporate Governance Structure}

Under the Italian system, the board of directors is a unitary body and a separate board of auditors is required. Unlike in the United States, the board of directors has a central role to play in the company's organizational structure. It is charged with providing strategic and organizational guidance and "verifying the existence of the controls needed to monitor" the company's performance. $^{69}$ 
In particular, in the model outlined in the Preda Code, the board of directors is comprised of "executive directors (i.e., the managing directors, and those directors who perform management functions within the company) and non-executive directors." ${ }^{\prime \prime 0}$ The chairman of the board plays a key role in ensuring compliance with the principles of corporate governance, as he is responsible for the work of the board, the distribution of the information to directors, and the coordination of the board's activities. Decision-making powers in the running of the company are delegated to the non-executive directors, whose number and authority should result in their carrying significant weight in board decisions.

The balanced composition of the board, with the participation of executive directors and non-executive directors, of which some are classifiable as "independent," the outcome of the confrontation and dialectic between management powers and those of strategic guidance and supervision, while ensuring that the necessary attention is paid to the performance of the company and the prevention of conflicts of interest.

The peculiar corporate governance structure of Italian corporations, as summarized above, explains why, to a large degree, the Italian system is not consistent with the U.S. model.

\section{Financial Certifications and the New Requirements for Executives}

\section{Directors}

The requirements under the Act and under Italian law are significantly different. Unlike the United States model, under the Italian system, no CEOs or CFOs' certification is required and there is a collective responsibility on the part of the entire board of directors for the probity of the company's financial statements (though any director is subject to criminal liability). ${ }^{72}$

In particular, financial statements should properly and faithfully present the company's economic and financial conditions. The shareholders at the company's annual shareholders' meeting approve the company's balance sheet, along with the directors' report. The financial statements of listed companies are to be filed along with both the report of the statutory auditors and the certification of an auditing firm.

70. Id.

71. "An adequate number of non-executive directors [has] to be independent, in the sense that they: (a) do not entertain ... business relationships with the company," its subsidiaries, the executive directors, or the shareholder or group of shareholders who controls the company; or (b) do not "own, directly or indirectly, ... . a quantity of shares enabling them to control the company ... or participate in shareholders' agreements to control the company." Id.

72. The board of directors' members are jointly and severally responsible for the damages resulting from inaccurate statements. However, as a general rule, Italian law does not provide for a collective criminal responsibility. Accordingly, any member of the board may be subject to criminal sanctions for inaccurate statements. 
According to the Preda Code, the responsibility for the internal control system of listed companies, i.e., "the set of processes serving to monitor ... the reliability of [the company's] financial information, [and the] compliance with laws and regulations," should lie with the board of directors. ${ }^{73}$ The board, with the assistance of the internal control committee and the persons appointed to run the internal control system, should lay down the guidelines for, and periodically check the functioning of, the internal control system. ${ }^{74}$

The managing directors [should] identify the main risks the company is exposed to and submit them to the board of directors for its examination; they [should] implement the guidelines laid down by the board of directors for the planning, operation and monitoring of the internal control system and should appoint one or more persons to run it and provide them with appropriate resources. ${ }^{75}$

"In companies that have an internal audit function, the person[s] appointed to run the internal control system can also be the head of the internal audit function." ${ }^{76}$ In companies that do not have an internal audit office, the Preda Code recommends that the board of directors should periodically assess the desirability of instituting one. ${ }^{77}$

The persons appointed to run the internal control system should report to the managing directors to allow them to intervene promptly where necessary and to the internal control committee and the board of auditors to keep them informed of the results of their work. ${ }^{78}$

In order to comply with the Act, a dual U.S. and Italian listed company must ensure that:

(i) the CEO or CFO is in a position to give the certifications in the prescribed form before approving any relevant accounts. Though the SEC has not prescribed any particular procedures for conducting a review of the company's controls and procedures, it has recommended that each company create a disclosure committee to ensure compliance with the relevant requirements; and

(ii) the design, implementation, and evaluation of internal financial and disclosure control structures and systems are sufficient for the purposes of the certification. The company may want to consider institut- 
ing an internal "cascade" certification process for key managers. ${ }^{79}$

\section{The Independent Oversight}

(i) Audit Committee. The requirements under the Act are broadly similar to those under Italian law. With respect to the composition of the committee, the main difference is that under the Act all members of the audit committee are required to be independent ${ }^{80}$ while the Preda Code provides for the establishment of an internal control committee (i.e., the "Comitato per il controllo interno"), which is comprised of non-executive directors whose majority shall be independent. ${ }^{81}$

In light of the above, it is clear that dual U.S. and Italian listed companies should review the members on their committees to assess whether they may satisfy the independence requirements under the Act.

Furthermore, as an additional requirement under the Act, a U.S. and Italian listed company should disclose whether or not a financial expert has been appointed to the audit committee. As a matter of fact, under the Preda Code, there is no specific requirement that the members of the Comitato per il controllo interno be a "financial expert," though they must have a general understanding of audit committee functions to perform their duties. ${ }^{82}$

Finally, under the ICC, the shareholders in a general meeting are responsible for appointing, and determining the compensation of, statutory auditors (with the exception of the first statutory auditors that are nominated under the company's articles of incorporation). This rule would appear to conflict with Rule 10A-3, proposed by the SEC, according to which the audit committee would be directly responsible for the appointment of auditors. ${ }^{83}$

(ii) Nominating Committee. The Preda Code suggests that listed companies in Italy should consider it helpful to establish a nominating committee to propose appointments for directors. Nonetheless, in Italy, the large proportion of companies with concentrated ownership, the legal requirement for appointments to the board of directors not to last more than three years, and the bylaws providing for election lists in some companies

79. Id.

80. This is, however, subject to certain exemptions for non-U.S. companies.

81. Id. Where another listed company controls a company, the Comitato per il controllo interno shall be comprised exclusively of independent directors.

82. The Comitato per il controllo interno is required, among other things, to: (a) assess the adequacy of the internal control system; (b) assess the work program prepared by the persons responsible for internal control and receive their periodic reports; and c) assess the proposals of auditing firms to obtain the audit engagement, the work program for carrying out the audit, and the results thereof as set out in the auditors' report and their letter of suggestions.

83. Although the SEC has maintained that the rule relates to the assignment of responsibility to oversee the auditor's work and that no conflict therefore arises. 
with a broad shareholder base make it not advisable to institutionalize such a committee.

Furthermore, unlike in the U.S. proposed reform, where the board of directors establishes a committee to propose candidates for appointment to the position of director, it is only the majority of the members of such committee that must be non-executive directors. In this respect, the recommendations contained in the Preda Code are not as strict as those made by the NYSE and by Nasdaq and the suggestions of the Conference Board Commission, which would urge for the establishment of a nominating committee comprised exclusively of independent directors.

(iii) Remuneration Committee. The Preda Code recommends that the board of directors of Italian listed companies should set up a remuneration committee. However, under Italian law there is no requirement that this committee be comprised exclusively of independent directors, as under the NYSE and Nasdaq proposals and under the Conference Board Commission's recommendations. The Preda Code recommends that only a majority of the committee's members be non-executive directors.

Furthermore, according to the Preda Code, the committee in question should submit proposals to the board on the remuneration of the managing directors and of those directors who are "appointed to particular positions in accordance with the articles of association." 84 In other words, in compliance with the features of the Italian system of corporate governance, the remuneration committee's function could be only to make proposals, while the power to establish the remuneration of top management would remain with the board of directors.

\section{Executive compensation}

Under Italian law, there is no provision similar to Section 304 of the Act. Directors of dual U.S. and Italian listed companies need to be aware of the possibility of a reimbursement in the event of restatement of financial information and ensure that the company seeks reimbursement under the circumstances contemplated by the Act.

Furthermore, a recent law has abrogated the rule under Article 2624 of the ICC, which was similar to the provision of Section 402 of the Act. As a consequence, companies are no longer forbidden to make loans to, or to provide guarantees for any personal debt of, directors, executive officers, or statutory auditors. ${ }^{85}$

84. Preda Code, supra note 62.

85. Article 2624 of the ICC has been abrogated by the Legislative Decree No. 61 (Apr. $11,2002)$. 


\section{Ethical conduct}

Though the Preda Code can be roughly compared to the corporate code of ethics, as provided for by Section 406 of the Act, the U.S. model appears to be stricter than the Italian position with respect to ethical conduct.

Under the Italian system, there is no specific job protection for employees who provide information regarding violation of securities or antifraud laws and retaliation would be prohibited under the shelter of the employment legislation. U.S. and Italian listed companies should, thus, consider establishing procedures for receiving and dealing with anonymous complaints.

\section{CONCLUSIONS}

The concerns raised by the extra-territorial application of the U.S. law, which is a critical issue in the debate concerning the scope of the provisions of the Act, should urge a reform of the Italian legal and regulatory framework regarding corporate governance.

On April 9, 2002, a commission of experts, headed by Professor Galgano, was set up with the purpose of assessing the need for such a reform. On September 27, 2002, Galgano presented to the Italian Ministry of Finance the commission's report, with recommendation that the suggested reform be implemented through Consob's regulations. ${ }^{86}$

The recommendations contained in the report mainly concern the accounting reform and the disclosure requirements for listed companies. With respect to corporate governance, the experts have focused especially on the issues of the directors' and auditors' independence and on the conflict of interest. $^{87}$ Most likely, the reason for this choice is that the requirement for independent directors and the risks involved in the conflict of interest are among the most critical issues that the recent corporate scandals in the United States have brought to light. Furthermore, the need to avoid situations of conflict of interest concerning directors of listed companies is particularly evident in the Italian system and has already called for the attention of Consob.

Nonetheless, though the independence requirement for directors and the absence of a conflict of interest are a conditio sine qua non, other steps should be taken to achieve the goal of a sound corporate governance structure of Italian listed companies. In particular, the independence of directors is not conclusive per se, as the procedure for their nomination, their powers and the mechanisms for their remuneration should also be scrutinized.

86. See Commissione di Studio sulla Trasparenza delle Societa' Quotate, at http://www.tesoro.it/DOCUMENTAZIONE/Commissione_Studio_trasp_soc_quotate.pdf. (last modified Sept. 27, 2002), for the report. In July 2003, the draft of a second report had been submitted to the attention of the Italian Ministry of Finance.

87. See id. at 36-39. 
The provisions of the Act might not be a model in this respect, given the number of inconsistencies between the Italian and the U.S. system of corporate governance, in terms of different corporate governance structures, as well as of different legal frameworks and different scope of the regulatory powers given to the competent supervisory authorities.

As a matter of fact, these inconsistencies are of the essence for dual U.S. and Italian listed companies, which might be required to review their structure and policy to assess whether they satisfy the requirements under the Act. Inter alia, these companies should consider the following key action points:

CERTIFICATIONS-Consider instituting a disclosure committee and an internal "cascade" certification process for key managers; establish a working group and procedures to review and test internal controls, disclosure controls, and procedures in light of the Act; determine what procedures are currently in place and what additional procedures may be necessary in order to permit the CEO and CFO to make the required certifications;

LOANS-Identify all outstanding loans and extensions of credit granted to or arranged for directors and executive officers as of July 30,2002 and establish procedures to prevent the renewal or material modification of such loans; review any option plan permitting cashless exercise transactions and any arrangement having the quality of a loan.

AUDIT COMMITTEE-Investigate whether all audit committee members are "independent"; review the company's audit committee charter in detail to ensure it provides sufficient authority to comply with proposed requirements; identify audit committee members who are "financial experts" and ensure that there is one on the audit committee.

$\checkmark$ CODE OF ETHICS-Review any existing code of ethics and, if the company does not have an existing code, consider adopting a formal code of ethics that meets the Act's requirements.

WHISTLEBLOWERS-Audit committees should consider procedures relating to complaints regarding accounting, internal controls, or auditing matters.

The reform of Italian rules should take into account the abovementioned issues and should also consider revising the system of sanctions, following the U.S. model while accommodating the specific situations in the Italian jurisdiction. In so doing, other circumstances should also be taken into account, such as the expected changes in the Italian corporate law, which will materially affect the corporate structure of Italian listed companies starting in 2004. 
The new provisions should be provided for by law and could be implemented through the Consob regulations. The current corporate governance code should also be revised and should play a substantial role in defining the new regulatory framework by means of "best practice" rules. 